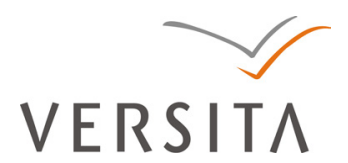

Folia Oeconomica Stetinensia

DOI: 10.2478/foli-2013-0012

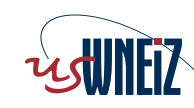

Wydzial Nauk Ekonomicznych i Zarządzania Uniwersytetu Szczecińskiego

\title{
COMPOSITE INDEX OF LOCAL GOVERNMENT \\ EMPLOYEES SATISFACTION
}

\author{
Bartłomiej Jefmański, Ph.D. \\ Wroctaw University of Economics \\ Faculty of Economics, Management and Tourism \\ Department of Econometrics and Computer Science \\ Nowowiejska 3, 58-500 Jelenia Góra, Poland \\ e-mail: bartlomiej.jefmanski@ue.wroc.pl
}

Krzysztof Błoński, Ph.D.

University of Szczecin

Faculty of Economics and Management

Marketing Department

Mickiewicza 64, 71-101 Szczecin, Poland

e-mail:kblonski@wneiz.pl

Received 4 September 2013, Accepted 17 January 2014

\begin{abstract}
The paper proposes a structure of a composite Index of Local Government Employees Satisfaction (ESI) in Poland. The index provides a based on four sub-indices synthetic assessment of the level of employee satisfaction with the employment in local government offices. The sub-indices have been constructed using an exploratory factor analysis with the VARIMAX one. The ESI and sub-indices values have been normalized in the range of [0-100\%], wherein higher ESI values indicate higher employee satisfaction. The proposed approach is used to assess the level of employee satisfaction with the employment in some local government units in the West Pomerania province. The analysis was based on the results of the measurements made in 2009-2010 by comparing the results of two groups of employees separated on the basis of a criterion of their place of employment.
\end{abstract}

Keywords: employee satisfaction, composite index.

JEL classification: J28, J45, C01. 


\section{Introduction}

Socio-economic transformations that have taken place in recent decades have also affected the functioning of the public sector in many countries. The previous traditional model of public administration based on Neo-Weberian bureaucracy and strongly referring to the concept of Fordism in the social version has been abandoned. In its place they started to implement a new model of public management. Its essence is to introduce to the public administration the economic mechanisms of competition as well as the logic and rules of the market, together with the relevant tools ${ }^{1}$. The main purposes of the new public management are: to improve the effectiveness of public institutions, to ameliorate the quality of public services, to increase operational efficiency and to recover public trust. This has increased the demand for information needed in the management of the given public organisation. This has also been reflected in the systems of measuring the public sector entities' achievements (Performance Measurement System). The basis of these systems are diverse indicators, the choice of which depends on the factors of subjective and objective nature, as well as on the purpose to be accomplished ${ }^{2}$.

The applied indices describe customer and employee satisfaction. Customer satisfaction indices can be presented as a separate index showing the status of a given $\operatorname{area}^{3}$ or as a part of a group of indices on the basis of which a multilateral analysis of the issue is carried out ${ }^{4}$. The employee satisfaction index in measurement systems of achievements also can also be a component of a group of indices. An example of this use of employee satisfaction indices is the Balanced Scorecard (BSC) by R.S. Kaplan and D.P. Norton ${ }^{5}$. The authors assumed the need of applying a system of indices that is not a universal, but specific to each organization. The selection of indices should make it possible to determine a degree of the purpose achievement, therefore they are linked in hierarchical cause and effect relations seen from the four perspectives: financial, customer's, internal processes, as well as learning and progress. In the customer's perspective a satisfaction index is used to determine the degree of customer satisfaction, while in the learning perspective - as one of the dimensions of the human capital assessment ${ }^{6}$.

The aim of this paper is to propose a new model for the assessment of employee satisfaction in the form of the Index of Local Government Employees Satisfaction. The proposed approach uses a methodology for the construction of composite indices. The index can be used by units of local government in the process of assessing both the satisfaction of an individual employee and of an organisation as a whole. It makes it possible to benchmark research in local government units, and to monitor changes in employee satisfaction over time. 


\section{Indices as statistical models for employee satisfaction assessment}

Indices as multivariate statistical models that aggregate information into a single numerical value permanently etched into the canon of methods of both external and internal customer satisfaction assessing. Popularity of the indices of satisfaction among researchers ensues from the fact that the concept of satisfaction is so complex that its measurement and evaluation cannot be based on information contained in individual variables. The main advantage of the proposed approach to using the indices is just the aggregation of multiple partial information so that we can characterize a complex phenomenon with a single number (the index of satisfaction value). It is hard to imagine an attempt to determine e.g. a ranking of local government units in terms of employee satisfaction by analysing separately each of the tens of variables having a potential impact on the level of the satisfaction. Satisfaction indices enable a researcher, in a very simple and user-friendly way, to assign a given ranking of objects (such as local government units) to the complex phenomenon which is the satisfaction of internal and external customers. The comparison of local government units is possible due to the fact that the indices are standardized in the specified range of values determined by the researcher. Additionally, this feature also allows the use of indices to monitor changes in the level of employee satisfaction, taking into account the time factor.

In a review of literature on the satisfaction research one can easily observe that it is much more likely to find some publications on the use of customer satisfaction indices than of the employee satisfaction ones. Among the measures of client satisfaction the best known are: the client satisfaction index (CSI), ACSI (American Customer Satisfaction Index), SCSB (Swedish Customer Satisfaction Barometer) and ECSI (European Customer Satisfaction Index). The CSI index is based on the model of multiple attribute attitudes and is expressed as the sum of the ratings which an entity assigns to an individual object. Originally, the basis for estimating the value of the index was the measure based on quantitative scales. Nowadays, one can also find the situation of determining the value of the index on the basis of measurements on an ordinal scale.

Another group of customer satisfaction indices are national indices of satisfaction. They are an expression of the tendency to use the satisfaction to measure the economic results achieved at the level of the country. This type of measurement differs from the previous efficiency measurements as it relates to the quality rather than the quantity. Therefore, customer satisfaction index has been recognized as a valuable complement to quantitative measures of economic accomplishments. Most indicated in this group are ACSI, SCSB and ESCI. The basis 
for their designation are structural equation models. Other notable models included in this group are: Norwegian Customer Satisfaction Barometer (NCSB), Korean Customer Satisfaction Index (KCSI), Malaysian Customer Satisfaction Index (MCSI) and Swiss Index of Customer Satisfaction (SWICS) ${ }^{7}$. This collection is constantly increasing by more satisfaction indices developed in further countries.

A separate group of indices regarding the subject of measurement are employee satisfaction indices. This group can include, among others, Job Satisfaction Index (JSI), Job Descriptive Index (JDI) and the Index of Organizational Reactions (IOR).

Job Satisfaction Index is a measure developed by Schriesheim and Tsui ${ }^{8}$. The measurement is based on six 5-point Likert-type scales. The aspects that are estimated on the basis of the above are: the degree of satisfaction with work itself, supervision, co-workers, pay, promotion opportunities and the job in general. The second measure is Job Descriptive Index, which was designed and developed by Smith et al. ${ }^{9}$ Originally the measure was based on 72 alternative nominal scales grouped into five sets including: the work itself, pay, promotions, supervision and co-workers. Gregson ${ }^{10}$ developed a shortened version consisted of six issues in each of the highlighted areas.

The latter itemized employee satisfaction measure - Index of Organizational Reactions were prepared by Dunham and Smith ${ }^{11}$ and relates to employee satisfaction with their work and with the organisation. The IOR assesses satisfaction with supervision, financial rewards, kind of work, physical conditions, mount of work, company identification, co-workers and careerfuture.

\section{Methodology of Local Government Employees Satisfaction Index}

In the construction of customer satisfaction indices so-called composite indices can also be applied. Their design is based on the use of a general pattern of proceeding, in which the main elements are: normalization and transformation of variables, determining the weightings for the individual variables and the adoption of appropriate aggregate function. As part of detailed steps the researchers making composite indexes use different multivariate statistical methods, wherein the most popular approach is the use of exploratory factor analysis. The offer of the ESI index described in this article also assumes the use of factor analysis. The developing details of the ESI using this method are described in the following paragraphs of the article. 


\subsection{Characteristics of the data set}

To construct the ESI index, the data set developed on the basis of the results of surveys carried out in the framework of the project "Implementation of management improvements in local government units in the area of the West Pomeranian Province" was used ${ }^{12}$. The study was conducted in the local government units in the West Pomeranian Province. The respondents were the employees of the local community and county offices. 611 individual interviews were conducted using the PAPI method (Paper and Pencil Interview). On the ground of the literature studies 23 variables have been selected (work-related aspects), which theoretically should have an impact on the level of employee satisfaction (Table 1).

Table 1. Description of variables used to the construction of the Index

\begin{tabular}{|c|l|}
\hline Symbol & \\
\hline$x_{1}$ & Timely handling of cases among co-workers at the office \\
\hline$x_{2}$ & Reliable handling of cases among co-workers at the office (no errors) \\
\hline$x_{3}$ & Other office staff's helpulness \\
\hline$x_{4}$ & Cooperation in handling cases between customers and other office staff \\
\hline$x_{5}$ & Helpfulness of the other office staff in emergency and crisis situations \\
\hline$x_{6}$ & Superior's helpfulness \\
\hline$x_{7}$ & Employees' sense of community within the office \\
\hline$x_{8}$ & Confidentiality (non-commenting) of customer cases by the office staff \\
\hline$x_{9}$ & Adequate knowledge and skills to the position held \\
\hline$x_{10}$ & Mutual respect and politeness at work \\
\hline$x_{11}$ & Job security \\
\hline$x_{12}$ & Desire to share information helpful in handling customer cases \\
\hline$x_{13}$ & Efficient circulation of information among employees \\
\hline$x_{14}$ & Adapting working hours to the needs of customers \\
\hline$x_{15}$ & Efficient flow of information between employees and their superiors \\
\hline$x_{16}$ & Clear requests formulated by the superior \\
\hline$x_{17}$ & Decor \\
\hline$x_{18}$ & Functionality of the workplace (space, lighting, etc.) \\
\hline$x_{19}$ & Availability of office facilities (fax, telephone, computer, copier) \\
\hline$x_{20}$ & Financial motivation \\
\hline$x_{21}$ & Non-financial motivation \\
\hline$x_{22}$ & Training \\
\hline$x_{23}$ & Opportunity of professional development \\
\hline & \\
\hline
\end{tabular}

Source: own study based study based on the results of the surveys.

Each aspects were rated by the respondents using a five-grade, estimated scale of measurement of the following points: very low, low, medium, high, very high. The integers in the range [1-5] were given to particular points at the stage of data coding. Prior to constructing the index the original variables were transformed using the following equation: 


$$
z_{i j}=\frac{x_{i j}-\min x_{i j}}{\max x_{i j}-\min x_{i j}}, i=(1,2, \ldots, n) ; j=(1,2, \ldots, k)
$$

where: $x_{i j}-j$ variable value for $i$ respondent.

The values of all variables were thus normalized in the range [0-1].

\subsection{Description of the approach used in the construction of the sub-indices}

Concepts such as employee satisfaction, by virtue of their complexity, can be generally divided into several separate issues that in the methodology of the composite indices construction are represented by the sub-indices. Their separation is possible through the use of multivariate statistical methods such as factor analysis. This approach has been applied, among others, for the construction of composite indices proposed by Tata and Schultz ${ }^{13}$, Boelhouwer and Stoop ${ }^{14}$, Lai ${ }^{15}$, Rygel et al. ${ }^{16}$, Antony and Rao ${ }^{17}$, Fukuda et al. ${ }^{18}$, Havard et al ${ }^{19}$, Fernando et al. ${ }^{20}$ In this paper, to construct the ESI index and sub-indices, factor analysis with VARIMAX rotation was also used. The outline applied at the creating the ESI index refers to the suggestions and recommendations of the OECD in the construction of composite indices. Particular information on how to deal with the construction of composite indices are presented in the study: Handbook on Constructing Composite Indicators. Methodology and User Guide ${ }^{21}$.

The ESI index construction involves the use of exploratory factor analysis at the stage of separation of the sub-indices and determination the weightings for the variables. The use of this method requires in the initial phase assessing the adequacy of the correlation matrix to the assumptions of the method. Therefore, before using factor analysis, a tentative selection of variables based on the KMO index (Kaiser-Meyer-Olkin) and MSA (Measure of Sampling Adequacy) was carried out. This procedure allows to eliminate variables between which the correlations are small, which may cause that the isolated factors will be difficult to interpret. The KMO index is calculated for the entire set of variables, whereas the MSA one is computed for each variable and it allows to eliminate individual variables before a proper analysis. The basis for the variable elimination are low values of the MSA index, which means that the variable cannot be explained by other variables. It was passed that the ESI index will include variables for which the MSA statistics will be greater than 0.5 . It was also assumed that the value of KMO statistics for all the variables is to be greater than 0.7 . The results of the analysis are presented in Table 2 . 
Table 2. The values of MSA statistics

\begin{tabular}{|c|c|c|c|}
\hline Variable & MSA statistics & Variable & MSA statistics \\
\hline$x_{1}$ & 0.909 & $x_{13}$ & 0.954 \\
\hline$x_{2}$ & 0.914 & $x_{14}$ & 0.950 \\
\hline$x_{3}$ & 0.934 & $x_{15}$ & 0.955 \\
\hline$x_{4}$ & 0.952 & $x_{16}$ & 0.923 \\
\hline$x_{5}$ & 0.939 & $x_{17}$ & 0.901 \\
\hline$x_{6}$ & 0.926 & $x_{18}$ & 0.770 \\
\hline$x_{7}$ & 0.971 & $x_{19}$ & 0.756 \\
\hline$x_{8}$ & 0.941 & $x_{20}$ & 0.886 \\
\hline$x_{9}$ & 0.964 & $x_{21}$ & 0.894 \\
\hline$x_{10}$ & 0.955 & $x_{22}$ & 0.903 \\
\hline$x_{11}$ & 0.954 & $x_{23}$ & 0.854 \\
\hline$x_{12}$ & 0.954 & - & - \\
\hline
\end{tabular}

Source: own calculations using IBM SPSS Statistics 21.

The KMO statistics value was 0.919 . The values of the MSA statistics for most variables were very high so it was decided that in the later stages of the ESI construction all the variables will be taken into account.

Determining the number of sub-indices using factor analysis is one of the essential stages of composite indices construction, which will have a significant impact on the next steps for the ESI index creating and the results of analyses carried out with its use. For this purpose, such criteria as: eigenvalues, percentage of variance criterion, Scree test criterion are used ${ }^{22}$. In the first of these it is proposed to approve the factors for which the eigenvalues are greater than unit. The second criterion requires that there should be as many components which together are responsible for the explanation of a specific part of variance (e.g. 60\%). The third criterion is based on visual estimate of the so-called scree plot. One should accept the number of factors which form a slope on the graph. The factors forming the scree are not taken into account. It should be noted that the suggested values of specified criteria have not been developed on the basis of the methodology of composite indices creating, but are commonly used in studies using factor analysis, the aim of which is to select the latent structures of multidimensional phenomena.

The principle component analysis was used to educe sub-indices. The decision on the number of sub-indices was taken on the basis of the indications of three criteria: the criterion of "eigenvalue greater than unity", the percentage of variance criterion and the scree test. The necessary calculations are listed in Table 3 and in Figure 1. 
Table 3. Factor analysis

\begin{tabular}{|c|c|c|c|}
\hline Factor & Eigenvalues & Variance $(\%)$ & $\begin{array}{c}\text { Cumulative } \\
\text { variance } \\
(\%)\end{array}$ \\
\hline 1 & 8.554 & 37.193 & 37.193 \\
\hline 2 & 2.375 & 10.328 & 47.521 \\
\hline 3 & 1.532 & 6.659 & 54.180 \\
\hline 4 & 1.156 & 5.028 & 59.208 \\
\hline 5 & 1.040 & 4.520 & 63.728 \\
\hline 6 & 0.828 & 3.599 & 67.327 \\
\hline 7 & 0.797 & 3.467 & 70.794 \\
\hline 8 & 0.741 & 3.220 & 74.014 \\
\hline 9 & 0.637 & 2.770 & 76.784 \\
\hline 10 & 0.608 & 2.642 & 79.426 \\
\hline 11 & 0.551 & 2.396 & 81.822 \\
\hline 12 & 0.515 & 2.238 & 84.060 \\
\hline 13 & 0.479 & 2.083 & 86.143 \\
\hline 14 & 0.416 & 1.810 & 87.953 \\
\hline 15 & 0.400 & 1.740 & 89.692 \\
\hline 16 & 0.381 & 1.658 & 91.350 \\
\hline 17 & 0.341 & 1.483 & 92.833 \\
\hline 18 & 0.332 & 1.445 & 94.278 \\
\hline 19 & 0.297 & 1.291 & 95.568 \\
\hline 20 & 0.276 & 1.199 & 96.768 \\
\hline 21 & 0.262 & 1.140 & 97.907 \\
\hline 22 & 0.253 & 1.102 & 99.009 \\
\hline 23 & 0.228 & 0.991 & 100.000 \\
\hline
\end{tabular}

Source: own study using IBM SPSS Statistics 21.

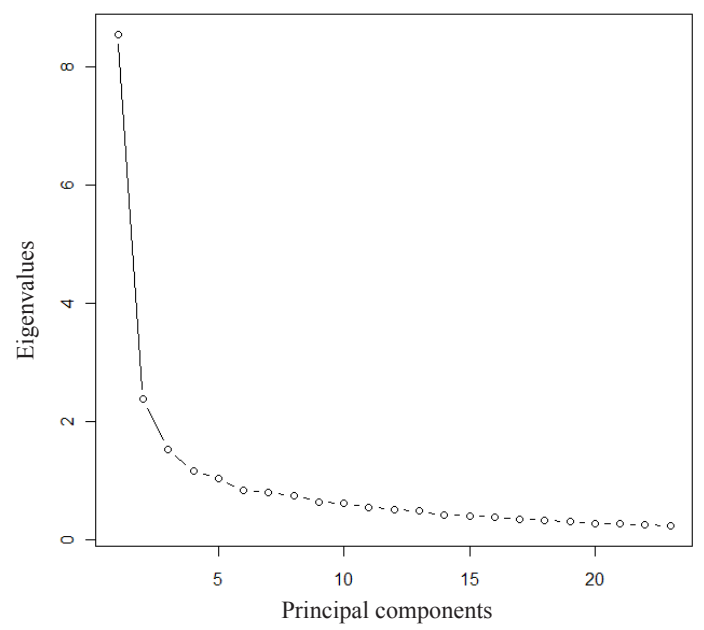

Fig. 1. Scree test

Source: own study using IBM SPSS Statistics 21. 
Due to the criterion of eigenvalues greater than unity, the results of the analysis suggest separating five factors. Taking into account the percentage of variance criterion four factors explain totally $60 \%$ of the variation and none of the further factors elucidates more than $5 \%$ of the variation. When analyzing the eigenvalues on the scree plot, it also seems that the number of factors should be 4 or 5 . Therefore, the applied criteria give no clear indication of the number of factors that should be taken, which is typical of exploratory factor analysis. As it is pointed out by $\mathrm{Sagan}^{23}$, the decision on the selection of a number of factors cannot be made solely on the basis of mechanical choices and requires a subjective decision of the researcher. In the present article it should have been resolved whether to accept four or five factors. The authors of the study adopt the variant that the ESI index will be composed of four sub-indices marked with the S symbol ${ }^{24}$. The fifth factor also explains only $4.5 \%$ of the variance and it complicates the structure of the whole model. The rest of the article confirms that the four sub-indices are a substantial interpretation, which is otherwise difficult in the case of the variant based on five sub-indices.

Table 4 summarizes the value of factor loadings on four factors that have been selected by means of the method of principle components.

Table 4. The values of factor loadings before rotation

\begin{tabular}{|c|c|c|c|c|}
\hline \multirow{2}{*}{ Variable } & $\mathrm{S}(1)$ & $\mathrm{S}(2)$ & $\mathrm{S}(3)$ & $\mathrm{S}(4)$ \\
\cline { 2 - 5 } & 1 & 2 & 3 & 4 \\
\hline 1 & 2 & 3 & 4 & 5 \\
\hline$x_{1}$ & 0.601 & -0.173 & 0.313 & 0.253 \\
\hline$x_{2}$ & 0.617 & -0.231 & 0.324 & 0.201 \\
\hline$x_{3}$ & 0.707 & -0.283 & 0.181 & 0.140 \\
\hline$x_{4}$ & 0.674 & -0.212 & 0.210 & 0.106 \\
\hline$x_{5}$ & 0.666 & -0.219 & 0.139 & 0.060 \\
\hline$x_{6}$ & 0.658 & -0.186 & -0.110 & -0.472 \\
\hline$x_{7}$ & 0.636 & -0.053 & -0.017 & 0.094 \\
\hline$x_{8}$ & 0.583 & -0.237 & -0.024 & 0.183 \\
\hline$x_{9}$ & 0.656 & -0.066 & -0.097 & 0.238 \\
\hline$x_{10}$ & 0.732 & -0.207 & -0.004 & 0.025 \\
\hline$x_{11}$ & 0.532 & 0.098 & -0.262 & -0.049 \\
\hline$x_{12}$ & 0.742 & -0.207 & 0.004 & 0.070 \\
\hline$x_{13}$ & 0.759 & -0.175 & 0.085 & -0.086 \\
\hline$x_{14}$ & 0.522 & -0.047 & -0.050 & 0.012 \\
\hline$x_{15}$ & 0.704 & -0.120 & -0.180 & -0.447 \\
\hline$x_{16}$ & 0.671 & -0.107 & -0.176 & -0.553 \\
\hline$x_{17}$ & 0.340 & 0.638 & 0.461 & -0.121 \\
\hline$x_{18}$ & 0.376 & 0.628 & 0.506 & -0.131 \\
\hline$x_{19}$ & 0.393 & 0.503 & 0.352 & -0.149 \\
\hline & & & & \\
\hline
\end{tabular}




\begin{tabular}{|c|c|c|c|c|}
\hline 1 & 2 & 3 & 4 & 5 \\
\hline$x_{20}$ & 0.528 & 0.549 & -0.231 & 0.098 \\
\hline$x_{21}$ & 0.600 & 0.440 & -0.233 & 0.095 \\
\hline$x_{22}$ & 0.518 & 0.394 & -0.386 & 0.255 \\
\hline$x_{23}$ & 0.572 & 0.402 & -0.467 & 0.191 \\
\hline
\end{tabular}

Source: own calculations using IBM SPSS Statistics 21.

In order to minimize the variables that have high values of factor loadings on the same factors the VARIMAX rotation is used. This allows to receive a much "simpler structure" of the factors (currently each variable has a high factor loading on only one factor) (Table 5).

Table 5. The values of factor loadings after the VARIMAX rotation and of variable importance

\begin{tabular}{|c|c|c|c|c|c|c|c|c|}
\hline \multirow{2}{*}{ Variable } & \multicolumn{4}{|c|}{ Factor loadings } & \multicolumn{4}{|c|}{ Variable importance } \\
\hline & $\mathrm{S}(1)$ & $\mathrm{S}(2)$ & $\mathrm{S}(3)$ & $\mathrm{S}(4)$ & $\mathrm{S}(1)$ & $\mathrm{S}(2)$ & $\mathrm{S}(3)$ & $\mathrm{S}(4)$ \\
\hline$x_{1}$ & $0.721^{*}$ & 0.062 & 0.013 & 0.172 & 0.097 & 0.001 & 0.000 & 0.013 \\
\hline$x_{2}$ & 0.742 & 0.013 & 0.071 & 0.154 & 0.102 & 0.000 & 0.002 & 0.010 \\
\hline$x_{3}$ & 0.759 & 0.096 & 0.209 & 0.061 & 0.107 & 0.003 & 0.016 & 0.002 \\
\hline$x_{4}$ & 0.699 & 0.090 & 0.202 & 0.128 & 0.091 & 0.003 & 0.015 & 0.007 \\
\hline$x_{5}$ & 0.655 & 0.113 & 0.256 & 0.085 & 0.080 & 0.004 & 0.024 & 0.003 \\
\hline$x_{6}$ & 0.342 & 0.112 & 0.755 & 0.061 & 0.022 & 0.004 & 0.207 & 0.002 \\
\hline$x_{7}$ & 0.518 & 0.299 & 0.225 & 0.085 & 0.050 & 0.028 & 0.018 & 0.003 \\
\hline$x_{8}$ & 0.595 & 0.210 & 0.161 & -0.079 & 0.066 & 0.014 & 0.009 & 0.003 \\
\hline$x_{9}$ & 0.569 & 0.398 & 0.136 & -0.002 & 0.060 & 0.050 & 0.007 & 0.000 \\
\hline$x_{10}$ & 0.635 & 0.229 & 0.350 & 0.025 & 0.075 & 0.017 & 0.045 & 0.000 \\
\hline$x_{11}$ & 0.236 & 0.442 & 0.333 & 0.037 & 0.010 & 0.062 & 0.040 & 0.001 \\
\hline$x_{12}$ & 0.663 & 0.243 & 0.315 & 0.023 & 0.082 & 0.019 & 0.036 & 0.000 \\
\hline$x_{13}$ & 0.627 & 0.166 & 0.426 & 0.135 & 0.073 & 0.009 & 0.066 & 0.008 \\
\hline$x_{14}$ & 0.389 & 0.245 & 0.249 & 0.059 & 0.028 & 0.019 & 0.023 & 0.001 \\
\hline$x_{15}$ & 0.332 & 0.221 & 0.761 & 0.067 & 0.020 & 0.015 & 0.211 & 0.002 \\
\hline$x_{16}$ & 0.262 & 0.176 & 0.830 & 0.094 & 0.013 & 0.010 & 0.251 & 0.004 \\
\hline$x_{17}$ & 0.072 & 0.164 & 0.022 & 0.847 & 0.001 & 0.009 & 0.000 & 0.309 \\
\hline$x_{18}$ & 0.114 & 0.143 & 0.037 & 0.881 & 0.002 & 0.006 & 0.000 & 0.334 \\
\hline$x_{19}$ & 0.123 & 0.175 & 0.122 & 0.702 & 0.003 & 0.010 & 0.005 & 0.212 \\
\hline$x_{20}$ & 0.100 & 0.711 & 0.119 & 0.337 & 0.002 & 0.160 & 0.005 & 0.049 \\
\hline$x_{21}$ & 0.199 & 0.685 & 0.174 & 0.278 & 0.007 & 0.149 & 0.011 & 0.033 \\
\hline$x_{22}$ & 0.170 & 0.773 & 0.052 & 0.093 & 0.005 & 0.189 & 0.001 & 0.004 \\
\hline$x_{23}$ & 0.154 & 0.832 & 0.149 & 0.073 & 0.004 & 0.219 & 0.008 & 0.002 \\
\hline Variance & 5.386 & 3.156 & 2.750 & 2.325 & & & & \\
\hline $\begin{array}{l}\text { Sub-index } \\
\text { importance }\end{array}$ & 0.40 & 0.23 & 0.20 & 0.17 & & & & \\
\hline
\end{tabular}

Source: own calculations using IBM SPSS Statistics 21. 
In sub-indices are constructed with the approach used in the study ${ }^{25}$. Only those variables that have the greatest factor loadings after rotation on a given factor affect the value of each sub-index. For example, let us take the variables $x_{1}$ and $x_{6}$. The values of the first of these will be taken into account when calculating the value of the first sub-index while the value of the variable $x_{6}$ will be taken when calculating the value of the third sub-index. The values of factor loadings after rotation allowed to interpret the particular sub-indices. Considering the variables which most strongly influence the particular sub-indices (have the biggest factor loadings), the authors adopted the names of the sub-indices listed in Table 6.

Table 6. Description of sub-indices

\begin{tabular}{|c|c|c|c|}
\hline Symbol & $\begin{array}{c}\text { Name of the } \\
\text { sub-index }\end{array}$ & Variables affecting the sub-index & $\begin{array}{l}\text { Reliability } \\
\text { of sub-index } \\
\text { (Cronbach's } \\
\text { Alpha) }\end{array}$ \\
\hline $\mathrm{S}(1)$ & $\begin{array}{l}\text { Cooperation } \\
\text { and relations } \\
\text { between } \\
\text { employees }\end{array}$ & $\begin{array}{l}\text { Timely handling of cases among co-workers at the office } \\
\text { Reliable handling of cases between co-workers at the office (no errors) } \\
\text { Other office staff's helpfulness } \\
\text { Cooperation in handling cases between customers and other office staff } \\
\text { Other office staff's helpfulness in emergency and crisis situations } \\
\text { The employees sense of community } \\
\text { The office staff's confidentiality (non-commenting) concerning customer } \\
\quad \text { cases } \\
\text { Adequate level of knowledge and skills to the position held } \\
\text { Mutual respect and politeness at work } \\
\text { Willingness to share information that can help in handling the customer } \\
\quad \text { cases } \\
\text { Efficient flow of information among employees } \\
\text { Adapting opening hours to the needs of customers }\end{array}$ & 0.897 \\
\hline $\mathrm{S}(2)$ & $\begin{array}{l}\text { Stable } \\
\text { professional } \\
\text { development }\end{array}$ & $\begin{array}{l}\text { Job security } \\
\text { Financial motivation } \\
\text { Non-financial motivation } \\
\text { Training } \\
\text { Opportunities of professional development }\end{array}$ & 0.820 \\
\hline $\mathrm{S}(3)$ & $\begin{array}{l}\text { Relationship } \\
\text { with the } \\
\text { superiors }\end{array}$ & $\begin{array}{l}\text { The superiors' helpfulness } \\
\text { Efficient flow of information between employees and superiors } \\
\text { Clarity of requests formulated by the superior }\end{array}$ & 0.854 \\
\hline$S(4)$ & $\begin{array}{l}\text { Workplace } \\
\text { equipment }\end{array}$ & $\begin{array}{l}\text { Decor } \\
\text { Functionality of the workplace (space, lighting, etc.) } \\
\text { Availability of office facilities (fax, telephone, computer, copier) }\end{array}$ & 0.804 \\
\hline
\end{tabular}

Source: own study based on the results of the surveys.

Table 5 presents the importance for each variable. It has been assigned as the result of squaring the factor loadings value after the rotation and then dividing the values by the value of the variance explained by the appropriate factor. In accordance to this approach, if we consider 
e.g. the variable $x_{6}$, its importance is: $0.207=(0.755)^{2} / 2.750$ In the same way the importance of e.g. the variable $x_{18}$ has been calculated, and it amounts to: $0.334=(0.881)^{2} / 2.325$. Table 5 also presents the importance for four sub-indices. The importance for the sub-indices reflects the involvement of the relevant factors in explaining the variance in the data set: $0.40=5.386$ / $(5.386+3.156+2.750+2.325)$ for the first one, 0.23 for the second, 0.2 for the third and 0.17 for the fourth one.

\subsection{Formula of the Index of Local Government Employees Satisfaction}

The values of individual sub-indices are the result of a linear combination of weighted variables adopted in the various sub-indices. The value of the ESI is calculated in a similar way - the values of sub-indices are multiplied by the importance assigned to them and then summed by means of a linear aggregation function. This approach is preferred when all variables are measured on the same scale of measurement ${ }^{26}$.

Before calculating the ESI one should compute the four sub-indices which are respectively written as the following formulas:

$$
\begin{gathered}
S(1)_{i}=0.097 x_{1 i}+0.102 x_{2 i}+0.107 x_{3 i}+0.091 x_{4_{i}}+0.08 x_{5 i}+0.05 x_{7 i} \\
+0.066 x_{8 i}+0.06 x_{9 i}+0.075 x_{10 i}+0.082 x_{12 i}+0.073 x_{13 i}+0.028 x_{14 i} \\
S(2)_{i}=0,062 x_{11 i}+0,16 x_{20 i}+0,149 x_{21 i}+0,189 x_{22_{i}}+0,219 x_{23 i} \\
S(3)_{i}=0.207 x_{6 i}+0.211 x_{15 i}+0.251 x_{16 i} \\
S(4)_{i}=0.309 x_{17 i}+0.334 x_{18 i}+0.212 x_{19 i}
\end{gathered}
$$

Conducting comparative studies of local government units using the ESI requires the normalisation in the specified range of values. For this purpose, the normalisation of four subindices by means of appropriate formulas has been effected as follows:

$$
\begin{aligned}
S(1)_{i}^{*} & =\left(\frac{S(1)_{i}-S(1)_{\min }}{S(1)_{\max }-S(1)_{\min }}\right) \times 100 \% \\
S(2)_{i}^{*} & =\left(\frac{S(2)_{i}-S(2)_{\min }}{S(2)_{\max }-S(2)_{\min }}\right) \times 100 \%
\end{aligned}
$$




$$
\begin{aligned}
& S(3)_{i}^{*}=\left(\frac{S(3)_{i}-S(3)_{\min }}{S(3)_{\max }-S(3)_{\min }}\right) \times 100 \% \\
& S(4)_{i}^{*}=\left(\frac{S(4)_{i}-S(4)_{\min }}{S(4)_{\max }-S(4)_{\min }}\right) \times 100 \%
\end{aligned}
$$

In the above equations in the normalisation of the sub-indices their minimum and maximum values are used. They are hypothetical values resulting from the substitution of the best and worst combinations of variables that affect a given sub-index. Having the standardized values of the sub-indices it is possible to take down the formula for the ESI for the $i$-th respondent as follows:

$$
E S I_{i}=0.4 S(1)_{i}^{*}+0.23 S(2)_{i}^{*}+0.2 S(3)_{i}^{*}+0.17 S(4)_{i}^{*}
$$

A similar approach, making use of the normalization of composite indices, was also applied in such studies as: Krishnan ${ }^{27}$, Antony and Rao $^{28}$, Hightower ${ }^{29}$, Sekhar et $\mathrm{al}^{30}$. However, in the above studies only the values of the composite index were normalized. In this paper, the authors have modified this approach by normalising not only the values of the ESI, but also of sub-indices. In this way it is possible to do comparative research between local government units from the point of view of the ESI as well as from the perspective of the results that are achieved in individual sub-indices.

The ESI is a stimulant, therefore, the higher its values, the higher the level of satisfaction among the employees. The ESI values are located in the range of [0-100\%]. It results from the fact that in order to estimate its value the authors use the linear aggregation function and the importance system for the sub-indices that are summed to unity. Therefore, the normalisation of the particular sub-index values in the range of [0-100\%] means that the final value of the ESI will also be included in the same range of values.

\section{The results of the assessment of satisfaction of local government employees in the West Pomeranian Province by means of the ESI}

The ESI was used to assess the level of satisfaction of local government employees located in the area of the West Pomeranian Province. For this purpose, the authors used the data from two parts of the employee surveys conducted under the project: 'Implementation of management improvements in local government units in the area of the West Pomeranian Province'. The first 
part of the survey was carried out in 2009. The results of that study were the basis for the ESI. The second part of the survey was completed in 2010 and was intended to evaluate the changes in the level of employee satisfaction over time. In the second part the research sample size was 469 respondents. The employees of the local county and community offices participated in both parts of the research. The use of the ESI allowed to compare the level of employee satisfaction in those two groups.

Prior to the appropriate analysis by means of the ESI, the authors estimated its value for all staff involved in the first part of the survey and then averaged the results (Table 7).

Table 7. The value of ESI and sub-indices for employees

\begin{tabular}{|c|c|}
\hline Designation & $\begin{array}{c}\text { Average value } \\
(\%)\end{array}$ \\
\hline $\mathrm{S}(1)$ & 67.14 \\
\hline $\mathrm{S}(2)$ & 57.54 \\
\hline $\mathrm{S}(3)$ & 69.92 \\
\hline $\mathrm{S}(4)$ & 63.15 \\
\hline $\mathrm{ESI}$ & 64.81 \\
\hline
\end{tabular}

Source: own calculations.

The estimated value of the ESI indicates that the level of job satisfaction among employees of local governments in West Pomerania Province can be considered as average. Out of the four sub-indices, the highest value was obtained by the third sub-index indicating the level of satisfaction with an employee's superior. The lowest employee ratings are connected with the stability of their professional development, which is evidenced by the value of the second subindex of about $57.54 \%$.

Then the value of the ESI and particular sub-indices are compared in two groups: the employees of the county and community offices (Table 8).

Table 8. The ESI and sub-indices value divided into two groups of employees

\begin{tabular}{|c|c|c|c|c|}
\hline \multirow{2}{*}{ Designation } & \multicolumn{2}{|c|}{ Average value (\%) } & \multirow{2}{*}{ F statistics } & \multirow{2}{*}{ p-value } \\
\cline { 2 - 3 } & counties & communities & & 0.68 \\
\hline $\mathrm{S}(1)$ & 66.98 & 67.36 & 0.17 & $<0.00$ \\
\hline $\mathrm{S}(2)$ & 55.78 & 60.02 & 12.45 & 0.46 \\
\hline $\mathrm{S}(3)$ & 69.53 & 70.48 & 0.55 & 0.78 \\
\hline $\mathrm{S}(4)$ & 63.31 & 62.93 & 0.08 & 0.06 \\
\hline ESI & 64.29 & 65.55 & 3.44 & 0.06 \\
\hline
\end{tabular}

The hypothesis of the average values of sub-indices diversity in the analysed groups of employees were tested at a significance level $\alpha=0.01$.

Source: own calculations using IBM SPSS 21Statistics. 
The ESI values suggest that the satisfaction level of county office employees is higher than the employees of community offices. This difference is not statistically significant and it barely amounts to 1.26 percentage points. Larger differences between the compared groups of employees can be observed at the level of some of the sub-indices. The highest statistically significant difference (at the significance level of $\alpha=0.01$ ), as it amounts to 4.24 percentage points, was observed in the values of the second sub-index. Thus, the evaluation of professional development stability most diversifies when comparing a group of employees and is better assessed among community offices employees. It should be noted that only one of the subindices has a lower value in the case of a group of community office employees and refers to the level of satisfaction with workplace equipment. In the other cases, the values of sub-indices are higher in community offices. The differences are small though, therefore the difference in the ESI for the compared groups is slight and it ranks the tested groups at the same level in terms of job satisfaction.

Finally, the ESI values changes that were observed within the period of 2009-2010 were compared separately for the groups of employees of both the county and community offices (Table 9 and 10).

Table 9. The ESI values change within the period of 2009-2010 for county office employees

\begin{tabular}{|c|c|c|c|}
\hline \multirow{2}{*}{ Symbol } & \multicolumn{2}{|c|}{$\begin{array}{c}\text { Average value } \\
(\%)\end{array}$} & \multirow{2}{*}{$\begin{array}{c}\text { Change } \\
(\%)\end{array}$} \\
\cline { 2 - 3 } & 2011 & 2012 & -0.13 \\
\hline $\mathrm{S}(1)$ & 66.98 & 66.89 & 0.13 \\
\hline $\mathrm{S}(2)$ & 55.78 & 55.85 & -0.58 \\
\hline $\mathrm{S}(3)$ & 69.53 & 69.13 & 0.06 \\
\hline $\mathrm{S}(4)$ & 63.31 & 63.35 & -0.14 \\
\hline ESI & 64.29 & 64.20 & \\
\hline
\end{tabular}

Source: own calculations.

Table 10. The ESI values change within the period of 2009-2010 for community office employees

\begin{tabular}{|c|c|c|c|}
\hline \multirow{2}{*}{ Symbol } & \multicolumn{2}{|c|}{$\begin{array}{c}\text { Average value } \\
(\%)\end{array}$} & \multirow{2}{*}{$\begin{array}{c}\text { Change } \\
(\%)\end{array}$} \\
\cline { 2 - 3 } & 2011 & 2012 & -1.13 \\
\hline $\mathrm{S}(1)$ & 67.36 & 66.60 & 1.50 \\
\hline $\mathrm{S}(2)$ & 60.02 & 60.92 & -1.06 \\
\hline $\mathrm{S}(3)$ & 70.48 & 69.73 & -0.03 \\
\hline $\mathrm{S}(4)$ & 62.93 & 62.91 & -0.40 \\
\hline ESI & 65.55 & 65.29 & \\
\hline
\end{tabular}

Source: own calculations. 
In both groups of employees the changes in the ESI and sub-indices values were very small. The ESI values fell in both cases, but a larger decrease was observed in the group of community office employees. The values of the sub-indices in the analysed period were more stable in the case of a group of county office employees. In none of the cases the changes in the sub-indices values exceeded 1 percentage point as for the absolute value. The values of sub-indices in the group of community office employees changed slightly. The largest positive change observed in the group was in the value of the second sub-index, i.e. the stability of professional development. The largest negative change was observed in the value of the first sub-index. That change suggests deterioration of cooperation and relationships among the employees in that group.

\section{Conclusions}

The proposed statistical model for assessing satisfaction of local government unit employees helps to estimate the level of employee satisfaction both at the level of the entire institution and of an individual employee or their groups. It also makes it possible to monitor the changes over a selected time period. The use of the exploratory factor analysis to its construction has allowed the authors to distinguish four hidden dimensions of employee satisfaction that are described by means of four sub-indices. Each sub-index is characterised by a different set of variables. In addition, the sub-indices have a different impact on the final ESI value through the use of the importance system. The approach proposed in the paper makes the assessment of the level of employee satisfaction simpler because a researcher can limit themselves to the analysis of the level of satisfaction with the use of five new variables (the ESI and four sub-indices) instead of analysing separately each out of the set of 23 variables. Being new variables, the subindices can be a starting point for further exploration and comparative analyses.

The use of the proposed approach to assessing satisfaction of local government unit employees in West Pomeranian Province in 2009-2010 allowed the authors to estimate that satisfaction with the work of these employees was at the average level. A slightly higher level of the ESI was seen in the analysed period in the case of employees of community offices. There were no significant changes in the ESI and the sub-indices in 2010 in comparison with the previous year. The values of the sub-indices suggest that the level of satisfaction of the employees of both county and community offices was the highest in the case of their relationship with superiors. The lowest level of satisfaction among the employees in both groups was observed in reference to the evaluation of the stability of their professional development. 


\section{Notes}

${ }^{1}$ Wojciechowski (2004), p. 604.

2 Strąk (2012), pp. 222-229.

${ }^{3}$ Poister (2003), pp. 47-45

${ }^{4}$ Artley, Strohn (2001).

${ }^{5}$ Kaplan, Norton (2010).

${ }^{6}$ Strąk (2012), pp. 222-229.

${ }^{7}$ Grigoroudis, Siskos (2010), p. 198.

${ }^{8}$ Fields (2002), pp. 16-35.

${ }_{9}$ Smith, Kendall, Hulin (1969).

${ }^{10}$ Fields (2002), pp. 16-35.

11 Ibidem.

12 The research was part of the task: Customer and Local Government Employees Satisfaction carried out in the framework of the project: Implementation of management improvements in local government units in the area of Western Pomerania province. Project manager: Prof. T. Lubińska, Ph.D., Szczecin University; task manager: Prof. Jolanta Witek, Ph.D.

13 Tata, Schultz (1988), pp. 580-593.

${ }^{14}$ Boelhouwer, Stoop (1999), pp. 51-75.

${ }^{15}$ Lai (2003), pp. 319-330.

${ }^{16}$ Rygel, O'Sullivan, Yarnal (2006), pp. 741-764.

17 Antony, Rao (2007), pp. 578-587.

${ }_{18}$ Fukuda, Nakamura, Takano (2007), pp. 163-173.

${ }^{19}$ Havard et al. (2008), pp. 2007-2016.

${ }^{20}$ Fernando, Samita, Abeynayake (2012), pp. 327-337.

${ }^{21}$ OECD (2008).

22 Kim, Mueler (1978).

23 Sagan (2004), p. 181.

${ }^{24}$ The authors of the article adopted principal component analysis and the most commonly used techniques for determining the number of factors as the method of selecting sub-indices. The validity of the solution based on four sub-indices was also confirmed by the results obtained using the method of maximum likelihood and chi-square test, as well as the likelihood ratio.

25 Nicoletti, Scarpetta, Boylaud (2000).

${ }^{26}$ Ebert, Welsch (2004), pp. 270-283.

27 Krishnan (2010).

28 Antony, Rao (2007), pp. 578-587.

${ }^{29}$ Hightower (1978), pp. 245-255

${ }^{30}$ Sekhar, Indrayan, Gupta (1991), pp. 246-250. 


\section{References}

Antony, G.M. \& Rao, K.V. (2007). A composite index to explain variations in poverty, health, nutritional status and standard of living: Use of multivariate statistical methods. Public Health, Vol. 121.

Artley, W. \& Strohn, S. (2001). The Performance - Based Management. Establishing an Integrated Performance Measurement. Performance-Based Management Special Interest Group, September 2001.

Boelhouwer, J. \& Stoop, I. (1999). Measuring well-being in the Netherlands: The SCP index from 1974 to 1997. Social Indicators Research, Vol. 48, No. 1.

Customer and Local Government Employees Satisfaction, carried out in the framework of the project: Implementation of management improvements in local government units in the area of Western Pomerania province. Project manager: T. Lubińska, J. Witek.

Ebert, U. \& Welsch, H. (2004). Meaningful environmental indices: A social choice approach. Journal of Environmental Economics and Management, Vol. 47, No. 2.

Fernando, M.A.C.S.S., Samita, S. \& Abeynayake, R. (2012). Modified Factor Analysis to Construct Composite Indices: Illustration on Urbanization Index. Tropical Agricultural Research, Vol. 23, No. 4.

Fields, D.L. (2002). Taking the Measure of Work. A Guide to Validated Scales for Organizational Research and Diagnosis. Sage Publications, Thousand Oaks.

Fukuda, Y., Nakamura, K. \& Takano. T. (2007). Higher mortality in areas of lower socioeconomic position measured by a single index of deprivation in Japan. Public Health, Vol. 121, No. 3.

Grigoroudis, E. \& Siskos Y. (2010). Customer Satisfaction Evaluation. Methods for Measuring and Implementing Service Quality. New York: Springer.

Havard, S., Deguen, S., Bodin, J., Louis, K. \& Laurent, O. (2008). A small-area index of socioeconomic deprivation to capture health inequalities in France. Social Science \& Medicine, Vol. 67, Issue 12.

Hightower, W.L. (1978). Development of an index of health utilizing factor analysis. Medical Care, Vol. 16.

Kaplan, R.S. \& Norton, D.P. (2010). Wdrażanie strategii dla osiagnięcia przewagi konkurencyjnej. Warszawa: Wydawnictwo Naukowe PWN.

Kim, J.O.\& Mueler, C.W. (1978). Factor Analysis. Statistical Methods and Practical Issues, Beverly Hills: Sage. 
Krishnan, V. (2010). Constructing an Area-based Socioeconomic Index: A Principal Components Analysis Approach, www.cup.ualberta.ca/wp-content/uploads/2013/04/ SEICUPWebsite_10April13.pdf(30.07.2013).

Lai, D. (2003). Principal component analysis on human development indicators of China. Social Indicators Research, Vol. 61, No. 3.

Nicoletti, G., Scarpetta, S. \& Boylaud, O. (2000). Summary indicators of product market regulation with an extension to employment protection legislation. OECD Publications, Economics Department Working Papers No. 226, Paris.

OECD (2008). Handbook on Constructing Composite Indicators. Methodology and User Guide, Paris: OECD Publications.

Poister, T.H. (2003). Measuring Performance in Public and Nonprofit Organizations. San Francisco: John Wiley \& Sons.

Rygel, L., O’Sullivan, D. \& Yarnal, B. (2006). A method for constructing a social vulnerability index: An application to hurricane storm surges in a developed country. Migration and Adaptation Strategies for Global Change, Vol. 11, Issue 3.

Sagan, A. (2004). Badania marketingowe. Podstawowe kierunki. Kraków: Wydawnictwo AE w Krakowie.

Sekhar, C.C., Indrayan, A. \& Gupta, S.M. (1991). Development of an index of need for health resources for Indian States using factor analysis. International Journal of Epidemiology, Vol. 20, No. 1.

Smith, P.C., Kendall, L.M. \& Hulin, C.L. (1969). The measurement of satisfaction in work and retirement. Chicago: Rand McNally.

Strąk, T. (2012). Modele dokonań jednostek sektora finansów publicznych. Warszawa: Difin.

Tata, R.J. \& Schultz, R.R. (1988). World variation in human welfare: A new index of development status. Annals of the Association of American Geographers, Vol. 78, Issue 4.

Wojciechowski, E. (2004). Mechanizmy rynkowe w sektorze publicznym. Gospodarka lokalna i regionalna w teorii i praktyce, Prace Naukowe Akademii Ekonomicznej we Wrocławiu nr 1023 . 